\title{
PERANAN KEARIFAN LOKAL DALAM PERATURAN DAERAH
}

\section{Eliza Meiyani}

\begin{abstract}
Local wise posses the important role in constructing the regency regulation namely as the support of procedure to make the better regency regulation as the material reference of regency regulation as the facility to increase the community loyalty towards the constructed regency regulation. The accommodation of local wise in constructing the regency regulation was not only can be seen as the form of appreciation towards the community rights but also the approval towards the basic rights of community (fundamental rights). Empirically every government (provincial and regency) in Indonesia posses the local value due to the decrease of land replacement to investor hand so the community become so difficult to obtain the adequate life, inaccessible to local community problem by regency government policy. Any obstacle faced by the existence of local value need to obtain the serious attention from regency government
\end{abstract}

Kata Kunci: Perda, kearifan, local

\section{Pendahuluan}

Pengakuan kedaulatan terhadap rakyat ini, dituangkan dalam UndangUndang Dasar Negara Republik Indonesia Tahun 1945 hasil amandemen yang mengandung prinsip demokratisasi, supremasi hukum dan penghormatan hak asasi manusia. Prinsip demokrasi ini tampak dalam Pasal 1 ayat (2) Undang-undang Dasar Negara Republik Indonesia tahun 1945 yang menentukan bahwa "Kedaulatan berada di tangan rakyat dan dilaksanakan menurut Undang-Undang Dasar". Salah satu bentuk pembuktian pengakuan terhadap kedaulatan rakyat adalah dengan pemberlakuan otonomi daerah oleh pemerintah pusat yang memberikan wewenang otonomi kepada daerah yang dalam hal ini adalah propinsi, kabupaten, dan kota untuk menyelenggarakan sendiri urusan rumah tangganya. Sehubungan dengan pemberian otonomi tersebut, maka pemerintah daerah diberikan kewenangan secara penuh mengurus rumah tangganya sendiri dan dituntut pula menggali dan mengelola sumbersumber pendapatan asli daerah secara optimal berdasarkan peraturan perundang-undangan yang berlaku. Oleh karena itu pemerintah daerah haras kreatif untuk mengembangkan dan meningkatkan kemampuannya baik dari segi sumber daya manusia maupun sistem dan prosedur yang digunakan dalam menunjang 
peningkatan pengelolaan penerimaan pendapatan asli daerah serta sistem pemberian pelayanan yang efisien dan efektif kepada masyarakat.

Pembentukan Perda dasarnya bukanlah suatu pekerjaan yang mudah, karena itu diperlukan orang-orang yang memiliki kapasitas tertentu (kapasitas di bidang ilmu dan ahli di bidang teknis perancangan). Salah satu hal yang harus dipahami oleh setiap perancang peraturan perundangundangan (legal drafting) adalah merumuskan secara baik dan benar landasan peraturan perundangundangan yang baik. Untuk dapat dikatakan sebagai peraturan yang baik maka suatu peraturan daerah harus memenuhi syarat yang dimuat secara tegas dalam Pasal 139 Undang-undang No. 32 tahun 2004 tentang Pemerintahan Daerah yang menyatakan bahwa masyarakat berhak memberikan masukan secara lisan atau tertulis dalam rangka penyiapan atau pembahasan rancangan peraturan daerah dan Pasal 137 Undang-undang No. 32 tahun 2004 tentang Pemerintahan Daerah yang menyebutkan bahwa pembentukan peraturan daerah harus sesuai dengan peraturan perundang-undangan seperti ada kejelasan, ada lembaga pembentuk, kesesuaian antara jenis dan materi muatan, dapat dilaksanakan, memiliki daya guna, jelas rumusannya dan terbuka.

Dalam teori hukum suatu produk hukum sebagai suatu kaidah harus dapat memenuhi 3 (tiga) kriteria untuk dapat dikatakan sebagai produk hukum yang memiliki keberlakuan yaitu: 1) Hukum berlaku secara yuridis apabila ketentuannya didasarkan pada norma yang lebih tinggi tingkatannya (menurut Hans Kelsen) atau bila terbentuk menurut cara yang ditetapkan (menurut W. Zevenbergen) atau bila menunjukkan keharusan antara suatu kondisi dan akibatnya (menurut J.H.A. Logemann) .2) Hukum berlaku secara sosiologis apabila kaidah tersebut dapat dipaksakan berlakunya meski masyarakat tidak menerima (menurut teori kekuasaan) atau kaidah tersebut berlaku karena diterima atau diakui masyarakat (menurut teori pengakuan).

3) Hukum tersebut berlaku secara filosofis jika sesuai dengan cita-cita hukum sebagai nilai positif tertinggi 
(Menurut Soeijono Soekanto,

Purbacaraka dan Lubis)

Peranan peraturan daerah
sangat penting dalam upaya menyelesaikan masalah-masalah sosial kemasyarakatan.

Suatu pemerintahan di daerah tanpa peraturan dan membiarkan masyarakat menyelesaikan sendiri masalahnya tanpa pedoman maka yang akan terjadi adalah ketidateraturan. Peraturan daerah yang dibutuhkan untuk dapat menjadi pedoman dalam penyelenggaraan pemerintahan di daerah adalah peraturan daerah yang respons terhadap tuntutan dan perkembangan masyarakat dalam rangka mewujudkan masyarakat yang demokratis dalam konteks negara kesejahteraan modern. Untuk dapat membentuk peraturan daerah yang berkualitas dibutuhkan adanya proses yang benar-benar dapat mengenali masalah yang ada di masyarakat dan memahami nilai yang ada di masyarakat sehingga dalam penyusunan peraturan daerah benarbenar harus mempertimbangkan kondisi masyarakat tempat peraturan tersebut akan diberlakukan. Pemahaman terhadap kondisi masyarakat tersebut kemudian menjadi pertimbangan dan acuan dalam melakukan penyusunan peraturan daerah sehingga akan diperoleh peraturan daerah yang benar-benar sesuai kondisi masyarakat bukan hanya merupakan perda yang dibentuk karena "trend" yang sedang ada, misalnya karena banyak daerah yang menyusun peraturan daerah yang tentang keharusan memakai jilbab bagi muslim maka daerah lain beramairamai membuat peraturan daerah serupa tanpa mempertimbangkan kondisi masyarakat di daerah tersebut, atau karena daerah yang lain beramairamai membentuk peraturan daerah tentang minuman keras maka daerah lainnya pun ikut membentuk perda yang sama.

\section{Kearifan Lokal Masyarakat}

Saini mengemukakan bahwa kearifan lokal dalam bahasa asing sering dikonsepsikan sebagai kebijakan setempat (local wisdom), pengetahuan setempat (local knowledge) atau kecerdasan setempat (Ideal genious). Kearifan lokal adalah sikap, pandangan, dan kemampuan suatu komunitas di dalam mengelola 
lingkungan rohani dan jasmaninya, yang memberikan kepada komunitas itu daya tahan dan daya tumbuh di dalam wilayah dimana komunitas itu berada. Dengan kata lain kearifan lokal adalah jawaban kreatif terhadap situasi geografis-geopolitis, historis, dan situasional yang bersifat lokal. Definisi lain tentang kearifan lokal adalah pandangan hidup dan ilmu pengetahuan serta berbagai strategi kehidupan yang berwujud aktivitas yang dilakukan oleh masyarakat lokal dalam dilakukan oleh masyarakat lokal dalam menjawab berbagai masalah dalam pemenuhan kebutuhan mereka .Sarlito Wirawan mengemukakan bahwa kearifan lokal atau sering disebut local wisdom dapat pula dipahami sebagai usaha manusia dengan menggunakan akal budinya (kognity) untuk bertindak dan bersikap terhadap sesuatu, objek, atau peristiwa yang terjadi dalam ruang tertentu.

Pengertian di atas, disusun secara etimologi, di mana wisdom dipahami sebagai kemampuan seseorang dalam menggunakan akal pikirannya dalam bertindak atau bersikap sebagai hasil penilaian terhadap sesuatu, objek, atau peristiwa yang terjadi. Sebagai sebuah istilah wisdom sering diartikan sebagai 'kearifan/kebijaksanaan. Local secara spesifik menunjuk pada ruang interaksi terbatas dengan sistem nilai yang terbatas pula. Sebagai ruang interaksi yang sudah didesain sedemikian rupa yang di dalamnya melibatkan suatu pola-pola hubungan antara manusia dengan manusia atau manusia dengan lingkungan fisiknya. Pola interaksi yang sudah terdesain disebut setting. Setting adalah sebuah ruang interaksi tempat seseorang dapat menyusun hubungan-hubungan face to face dalam lingkungannya. Sebuah setting kehidupan yang sudah terbentuk secara langsung akan memproduksi nilainilai. Nilai-nilai tersebut yang akan menjadi landasan hubungan mereka atau menjadi acuan tingkah-laku mereka. Proses evolusi yang begitu panjang dan melekat dalam masyarakat dapat menjadikan kearifan lokal sebagai sumber energi potensial dari sistem pengetahuan kolektif masyarakat untuk hidup bersama secara dinamis dan damai. Pengertian ini melihat kearifan lokal tidak sekedar sebagai acuan tingkah-laku seseorang tetapi lebih jauh yaitu mampu 
mendinamisasi kehidupan masyarakat yang penuh keadaban. Secara substansial, kearifan lokal itu adalah nilai-nilai yang berlaku dalam suatu masyarakat. Nilai-nilai yang diyakini kebenarannya dan menjadi acuan dalam bertingkah-laku sehari-hari masyarakat setempat. Oleh karena itu, sangat beralasan Greertz1 mengatakan bahwa kearifan lokal merupakan entitas yang sangat menentukan harkat dan martabat manusia dalam komunitasnya. Hal itu berarti kearifan lokal yang di dalamnya berisi unsur kecerdasan kreativitas dan pengetahuan lokal dari para elit dan masyarakatnya adalah yang peradaban masyarakatnya. Kearifan lokal merupakan pengetahuan eksplisit akan muncul dari periode panjang yang berevolusi bersama-sama masyarakat dan lingkungannya dalam sistem lokal yang sudah dialami bersama-sama. Proses evolusi yang begitu panjang dan melekat dalam masyarakat dapat menjadikan kearifan lokal sebagai sumber energi potensial dari sistem pengetahuan kolektif masyarakat untuk hidup bersama secara dinamis dan damai. Pengertian ini melihat Kearifan lokal tidak sekedar sebagai acuan tingkah-laku seseorang, tetapi lebih jauh yaitu mampu mendinamisasi kehidupan masyarakat yang penuh keadaban.

Kearifan lokal lahir dan berkembang dari generasi ke generasi seolah-olah bertahan dan berkembang dengan sendirinya. Kelihatannya tidak ada ilmu atau teknologi yang mendasarinya. Tidak ada pendidikan dan pelatihan untuk meneruskan kearifan lokal. Pada dasamya manusia menciptakan budaya dan lingkungan sosial mereka sebagai adaptasi terhadap lingkungan fisik dan biologisnya. Kebiasaan-kebiasaan, praktik, dan tradisi diwariskan dari generasi ke generasi. Pada gilirannya kelompok atau ras tersebut tidak menyadari dari mana asal warisan kebijaksanaan tersebut. Generasi berikutnya terkondisikan menerima 'kebenaran' itu tentang nilai, pantangan, kehidupan, dan standar perilaku.

Individu-individu cenderung menerima dan percaya apa yang dikatakan budaya mereka. Seseorang dipengaruhi oleh adat dan pengetahuan masyarakat di mana ia dibesarkan dan tinggal dan cenderung mengabaikan 
atau menolak apa yang bertentangan dengan kepercayaan-kepercayaan.

Teezzi Marchettini dan Rosini mengatakan bahwa akhir dari sedimentasi kearifan lokal ini akan mewujud menjadi tradisi atau agama. Dalam masyarakat, kearifan lokal dapat ditemui dalam nyayian, pepatah, sasanti, petuah, semboyan, dan kitabkitab kuno yang melekat dalam perilaku sehari-hari. Peranan Kearifan Lokal dalam Pembentukan Perda.

Pelaksanaan otonomi daerah menggariskan adanya pendelegasian wewenang(desentralisasi) kepada daerah dalam administrasi pembangunan di daerah, yaitu makin meningkatkan dan memantapkan kewenangan yang lebih besar kepada daerah mulai dan tahap perencanaan, pelaksanaan, pengendalian, pengawasan, dan pelaporan. Pendelegasian wewenang kepada daerah tahap perencanaan, pelaksanaan, pengendalian, pengawasan, dan pelaporan. Pendelegasian wewenang kepada daerah pada dasamya bukan hanya diselenggarakan oleh lembaga publik pemerintah (misalnya pemerintah daerah) namun juga oleh lembaga publik milik masyarakat yang dikelola secara mandiri oleh masyarakat (misalnya lembaga swadaya masyarakat lokal). Dalam hal ini pemerintah pusat hanya berperan sebagai fasilitator. Tetapi jika dalam beberapa hal tertentu belum dapat dilenggarakan oleh daerah, maka pemerintah pusat dapat memberikan bantuan kepada daerah (medebewind'), misalnya jika suatu kegiatan pembangunan itu merupakan pembangunan lintas daerah, lintas kawasan, atau lintas sektor. Dalam pelaksanaan otonomi daerah pada dasamya pemerintah pusat memberikan wewenang luas kepada daerah, terutama kepada pemerintah daerah untuk menyelenggarakan kegiatan diwilayah administratif mereka sendiri. Daerah (masyarakat lokal dan pemerintah daerah) menyelenggarakan kegiatan sosial ekonomi seluas mungkin. Sementara pemerintah pusat memberikan fasilitas dan melaksanakan kebijaksanaan fiskal, mulai dari menarik pajak hingga mendistribusikan kembali dalam bentuk bantuan pembangunan pada sasaran pembangunan yang paling membutuhkan pengaturan, pembagian 
dan pemanfaatan sumberdaya nasional tersebar di seluruh daerah pada dasarnya merupakan wewenang daerah untuk mengelolanya secara optimal. Namun berdasarkan pertimbangan kepentingan nasional di mana beberapa daerah secara nyata adalah daerah yang memiliki sumberdaya alam maupun sumberdaya manusia dan teknologi yang terbatas maka pemerintah pusat dapat berwenang dalam melakukan kebijaksanaan pemerataan pembangunan yang dilakukan secara berkeadilan. Kebijaksanaan pemerataan merupakan suatu kepentingan nasional yang mempunyai tujuan sesuai dengan lima si la Pancasila, temtama mewujudkan landasan kesejahteraan sosial bagi seluruh rakyat Indonesia.

Terminologi pemberdayaan masyarakat \{ community empowerment) kadang-kadang sangat sulit dibedakan dengan penguatan masyarakat serta pembangunan masyarakat \{community development). Dalam prakteknya seringkali terminologi - terminologi tersebut saling tumpang tindih, saling menggantikan dan mengacu pada suatu atau pengembangan masyarakat menuju ke arah yang positif. Pengembangan masyarakat sebagai suatu hal yang memiliki pusat perhatian dalam membantu masyarakat pada berbagai tingkatan umur untuk tumbuh dan berkembang melalui berbagai fasilitasi dan dukungan agar mereka mampu memutuskan, merencanakan dan mengambil tindakan untuk mengelola dan mengembangkan lingkungan fisiknya serta kesejahteraan sosialnya, dikembangkan masyarakat.

\section{Pemberdayaan masyarakat} merupakan alat untuk menjadikan masyarakat semakin komplek dan kuat. Ini merupakan suatu perubahan sosial dimana masyarakat menjadi lebih komplek, institusi lokal tumbuh, collective power meningkat serta terjadi perubahan secara kualitatif pada organisasinya. Berdasarkan persinggungan dan saling menggantikannya pengertian community development dan community empowerment, secara sederhana, maka pemberdayaan masyarakat merupakan upaya yang disengaja untuk memfasilitasi 
masyarakat lokal dalam merencanakan, memutuskan dan mengelola sumberdaya lokal yang dimiliki melalui collective action dan networking sehingga pada akhirnya mereka memiliki kemampuan dan kemandirian secara ekonomi, ekologi, dan sosial. Lingkungan strategis yang dimiliki oleh masyarakat lokal antara lain mencakup lingkungan produksi, ekonomi, sosial dan ekologi. Melalui upaya pemberdayaan, warga masyarakat didorong agar memiliki kemampuan untuk memanfaatkan sumberdaya yang dimilikinya secara optimal serta terlibat secara penuh dalam mekanisme produksi, ekonomi, sosial dan ekologinya. Dalam hal mekanisme produksi, masyarakat memiliki asset/sumberdaya produksi yang antara lain mencakup lahan, ternak, modal, peralatan usaha tarn serta tenaga kerja. Upaya pemberdayaan semestinya memfasiltasi dan mendorong masyarakat untuk mampu memanfaatkan sumberdaya produksi yang dimilikinya sehingga mampu berproduksi secara efisien dan menjamin pemenuhan kebutuhan ekonomi, sosial, budaya dan ekologi.
Aspek penting dalam suatu program pemberdayaan masyarakat adalah program yang disusun sendiri oleh masyarakat, mampu menjawab kebutuhan dasar masyarakat, mendukung keterlibatan kaum miskin dan kelompok yang terpinggirkan kebutuhan dasar masyarakat, mendukung keterlibatan kaum miskin dan kelompok yang terpinggirkan lainnya, dibangun dari sumber daya lokal, sensitif terhadap nilai-nilai budaya lokal, memperhatikan dampak lingkungan, tidak menciptakan ketergantungan, berbagai pihak terkait terlibat (instansi pemerintah, lembaga penelitian, perguruan tinggi, LSM, swasta dan pihak lainnya), serta dilaksanakan secara berkelanjutan.

Asas keterbukaan sebagai salah satu syarat minimum dari demokrasi terungkap pula dalam pendapat Couwenberg dan Sri Soemantri Mertosoewignjo. Menurut S .W. Couwenberg, lima asas demokratis yang melandasi rechtsstaat, dua di antaranya adalah asas pertanggungjawaban dan asas publik (openbaarheidsbeginsel), yang lainnya adalah: asas hak-hak politik, asas mayoritas, dan asas perwakilan. 
Senada dengan itu, Franz MagnisSuseno mengemukakan bahwa ide demokrasi menjelmakan dirinya dalam lima hal, dua diantaranya adalah: pemerintah harus bersikap terbuka (openbaarheid van bestuur) dan imungkinkannya rakyat yang berkepentingan menyampaikan keluhannya mengenai tindakantindakan penjabat yang dianggap merugikan.

Philippe Nonet dan Philip Selznick2 mengemukakan suatu teori mengenai tiga keadaan dasar hukum dalam masyarakat yang salah satu diantaranya adalah hukum responsif, yaitu hukum yang merupakan sarana respons atas kebutuhan dan aspirasi masyarakat. Penerapan teori ini pada pembentukan Perda berarti memberi peluang kepada warga masyarakat untuk berperan serta dalam pembentukan Perda. Membangkitkan nilai-nilai daerah untuk kepentingan pembangunan menjadi sangat bermakna bagi peijuangan daerah untuk mencapai prestasi terbaik. Selama ini, kearifan lokal dikalahkan bersama kepentingan pembangunan yang bersifat sentralistik dan top down. Oleh karena itu, sudah saatnya untuk menggali lebih banyak kearifankearifan lokal sebagai alat atau earn mendorong pembangunan daerah sesuai daya dukung daerah dalam menyelesaikan masalah-masalah daerahnya secara bermartabat. Hukum hanya memberikan kerangka ideologis dalam perubahan-perubahan sosial yang dikehendaki sebagai jaminan orang akan diperlakukan sama. Hal ini sangat kepada siapa saja. Secara normatif UUD 1945 secara tegas menyatakan bahwa Indonesia berdasarkan negara hukum, bukan negara kekuasaan. Segala sesuatu kebijakan yang diambil oleh pemerintah dan institusi negara lainnya harus berdasarkan kepada hukum. Dengan demikian konstitusi yang telah diciptakan tersebut untuk mengatur dan membatasi tindakan-tindakan pemerintah dan rakyat dalam melaksanakan tugas dan kewajiban masing-masing. Tentunya konstitusi yang dibuat itu tidaklah statis namun dinamis, yaitu mengikuti perkembangan yang terjadi dalam masyarakat. Oleh karena itu konstitusi dapat saja diubah karena tidak sesuai lagi dengan kondisi yang ada, sebagaimana yang telah dilakukan 
mulai dari tahun 1999 sampai dengan tahun 2002, melalui perubahan pertama sampai dengan perubahan keempat, hal ini dengan tujuan untuk menjaga stabilitas roda kenegaraan, agar tidak terjadi kekacauan. Sehubungan dengan itu maka pembentukan hukum harus memperlihatkan kesadaran hukum masyarakat. Di samping itu tidak tertutup kemungkinan bahwa hukum menciptakan pola-pola baru di dalam masyarakat, sehingga pada akhirnya menciptakan kesadaran hukum baru sesuai dengan kondisi yang dibutuhkan. Suatu sistem hukum yang modem haruslah merupakan hukum yang baik, dalam arti hukum tersebut harus mencerminkan rasa keadilan bagi semua pihak dan sesuai dengan kondisi masyarakat. Hukum dibuat sesuai dengan prosedur yang telah ditentukan, dan juga hams dimengerti atau dipahami oleh masyarakat secara keseluruhan. Supaya hukum benarbenar dapat mempengaruhi perilaku warga masyarakat, maka ketentuan hukum tersebut hams disebarluaskan sehingga melembaga dalam masyarakat. Adanya alat komunikasi merupakan salah satu syarat bagi penyebaran serta pelembagaan hukum, baik secara formal maupun informal, sehingga apa yang diinginkan oleh hukum dapat tercapai. Dari sini kelihatan bahwa jaminan terhadap negara hukum itu adalah ditentukan oleh dua persoalan, yaitu apakah hukumnya dibuat melalui proses yang sesuai dan kemudian diratifikasi secara demokratis, serta apakah hukum itu ditaati dan dilaksanakan oleh pemerintah maupun oleh rakyat yang diperintahnya secara tersurat maupun tersirat. Jawaban positif terhadap kedua hal ini menentukan juga kadar keseimbangan politik yang dihasilkan secara demokratis, serta apakah hukum itu ditaati dan dilaksanakan oleh pemerintah maupun oleh rakyat yang diperintahnya secara tersurat maupun tersirat. Jawaban positif terhadap kedua hal ini menentukan juga kadar keseimbangan politik yang dihasilkan oleh konstitusi (hukum) yang bersangkutan. Dari pernyataan ini dapat dipahami bahwa konstitusi (hukum) suatu negara, harus dibuat berdasarkan keseimbangan politik yang ada. Sehingga hukum itu dapat mengakomodir semua kalangan dan tidak cenderung menguntungkan salah 
satu pihak. Di sinilah perlu adanya kesamaan pandangan atau persepsi terhadap kandungan dari peraturan hukum yang diciptakan dari berbagai pihak, baik dari unsur masyarakat, partai politik, organisasi sosial maupun pemerintah dan lembaga-lembaga kenegaraan lainnya. Hukum yang baik adalah hukum yang dapat diterima dan ditaati oleh masyarakat. Untuk dapat diterima dan ditaati maka pembentukannya harus melibatkan masyarakat. Keterlibatan ini akan mendukung terwujudnya suatu Perda yang dibentuk melalui prosedur yang baik, memiliki substansi yang baik dan memiliki output yang baik. Disinilah keterkaitan antara kearifan lokal dengan pembentukan Perda menemukan titik temu untuk menemukan peran kearifan local dalam Perda.

\section{Kearifan lokal mendukung ketaatan masyarakat terhadap Perda}

Dalam kehidupan masyarakat, jauh sebelum lahirnya norma hukum, masyarakat telah mengenai norma lain yang menjadi pedoman dalam melakukan interaksi sosial. Norma ini hidup dan dipelihara turun temurun bahkan menjadi sebuah kepercayaan bagi masyarakat. Jika nilai-nilai ini kemudian diakomodir dalam Perda maka tingkat keataatan masyarakat terhadap Perda akan lebih baik karena melaksanakan Perda sama dengan mengikuti kepercayaan mereka. Jadi, dari uraian di atas penulis berpendapat bahwa ada 3 (tiga) peranan kearifan lokal yaitu : 1. Dapat dijadikan sebagai nilai dalam prosedur pembentukan Perda yang baik. Peranan ini dapat mendukung terbentuknya Perda yang memenuhi syarat formal.; 2. Dapat dijadikan sebagai acuan dalam penentuan materi muatan Perda. Peranan ini dapat mendukung terbentuknya perda yang memenuhi syarat substantive, 3. Dapat dijadikan sebagai mendukung ketaatan masyarakat dan terwujudnya keadilan karena dapat menjadi pendukung tercapainya tujuan hukum yaitu kepastian hukum, kemanfaatan dan keadilan. Kearifan lokal tidak selamanya dapat mendukung efektivitas pemberlakuan Perda. Oleh karena itu, untuk dapat mewujudkan Perda yang baik maka para pembentuk Perda harus mencermati beberapa hal yaitu : 1. nilai-nilai lokal yang layak 
untuk menjadi acuan dalam pembentukan Perda, baik sebagai acuan formal maupun acuan substansi adalah Perda yang memiliki muatan positif dalam pembangunan masyarakat ke arah yang lebih baik. 2 . Nilai lokal yang tidak bertentangan dengan hak-hak dasar yang ditegaskan dalam konstitusi. Sebagai contoh Perda tentang keharusan mengaji bagi calon PNS bertentangan dengan hak dasar masyarakat untuk memperoleh pekerjaan dan penghidupan yang layak. 3. Nilai lokal yang tidak menimbulkan keresahan dalam masyarakat. Sebagai contoh, pemberlakuan Perda tentang lokalisasi di Banteng menimbulkan keresahan masyarakat karena dianggap sebagai suatu Perda yang melegalkan pelacuran. 4. Nilai lokal yang tidak bertentangan dengan jiwa dari negara kesatuan. Sebagai contoh Perda tentang Syariat Islam yang diberlakukan di suatu daerah menyebabkan masyarakat daerah lain yang tidak beragama Islam enggan untuk tinggal atau mencari pekerjaan di daerah tersebut. Interaksi yang tidak jarang menimbulkan gesekan-gesekan tertentu hendaknya bisa segera diredam dengan nilai local knowledge (pengetahuan lokal) yang mengarah pada local wisdom (kearifan lokal). Pada dasarnya suatu kebudayaan berikut nilai-nilai yang terkandung di dalamnya selalu mengalami perkembangan, sehingga perlu dilakukan reinventarisasi, reinterpretasi, revitalisasi, dan reaktualisasi, sehingga tetap dapat menyesuaikan dengan perkembangan zaman. Hubungan yang seimbang antara keduanya akan mampu menyajikan kehidupan harmonis yang mempersyaratkan semua yang menjadi bagian lingkungan untuk tidak saling merusak.

Kesimpulan Dari uraian di atas disimpulkan bahwa kearifan lokal memiliki peranan penting dalam pembentukan Perda yaitu sebagai pendukung prosedur pembentukan Perda yang baik, sebagai acuan materi muatan Perda yang akan dibentuk, sebagai sarana untuk meningkatkan ketaatan masyarakat terhadap Perda yang dibentuk. Diakomodimya kearifan lokal pembentukan Perda yaitu sebagai pendukung prosedur pembentukan Perda yang baik, sebagai acuan materi muatan Perda yang akan 
dibentuk, sebagai sarana untuk meningkatkan ketaatan masyarakat terhadap Perda yang dibentuk. Diakomodimya kearifan lokal dalam pembentukan Perda tidak hanya dapat dilihat sebagai suatu bentuk penghargaan terhadap masyarakat daerah tetapi lebih dari itu, merupakan suatu pengakuan terhadap hak-hak dasar masyarakat (fundamental rights). Secara empiris, setiap daerah (provinsi dan kabupaten) di Indonesia, memiliki nilai lokal. Namun keberadaan kearifan lokal ini dihadapkan dengan berbagai permasalahan, antara lain semakin berkurangnya ruang gerak masyarakat lokal karena menyempitnya tanah yang pindah ke tangan investor, sehingga masyarakat tersebut semakin kesulitan dalam memperoleh penghidupan yang layak, tidak teijangkaunya masalah-masalah masyarakat lokal oleh kebijakan pemerintah daerah. Berbagai hambatan yang dialami oleh keberadaan nilai lokal perlu untuk memperoleh perhatian yang serius dari pemerintah daerah.

\section{DAFTAR PUSTAKA}

Achmad Ali. 2004. Meluruskan Jalan Reformasi Hukum. Agatama
Press: Jakarta .2002. Menguak Tahir Hukum (Suatu Kajian Filosofis dan Sosiologis). GunungAgung: Jakarta

Achmad Ruslan. 2006. Pembentukan Perundang-undangan yang Berkualitas. PT Binarena Pariwara: Jakarta

Aminuddin Ilmar. Hubungan Kewenangan Antara

Pemerintah Dengan Pemerintah Daerah Dalam Rangka Meningkatkan Demokratisasi Pemerintahan. Pidato Pengukuhan Pada Upacara Penerimaan jabatan Guru Besar dalam Bidang Ilmu Hukum Tata Negara dan Administrasi Negara pada Fakultas Hukum Universitas Hasanuddin Makassar, tanggal 6 Juni2007

Amrah Muslimin. 1986. Aspek-aspek Otonomi Daerah. Alumni :Bandung

Arief Sidharta. 1999. Refleksi Tentang Hukum. Citra Aditya Bhakti : Bandung

Azhary. 1995. Negara Hukum Indonesia . Ul-Press: Jakarta

A.Hamid S. Attamimi. Der Rechtsstaat Republik Indonesia dan Perspektijhya Menurui Pancasila dan UUD 1945. Makalah pada Seminar Sehari 
dalam Rangka Dies Natalis Universitas 17 Agustus Jakarta ke-42. diselenggarakan oleh FH Universitas 17 Agustus Jakarta. 9 Juli 1994

-Teori Perundang-Undangan Indonesia. Pidato Pengukuhan jabatan Guru Besar Tetap Fakultas Hukum UI. Jakarta 25 April 1992

-Peranan Keputusan Presiden Republik Indonesia Dalam Penyelenggaraan Pemerintahan Negara - suatu Studi Analisis

Bagir Manan. Hubungan Antara Pusat dan Daerah Menurut UUD 1945. Armico : Bandung

-------- 1993. Perjalanan Historis Pasal 18 UUD 1945 (Perumusan dan UndangUndang Pelaksananya). Unsika Kerawang

1992. Dasar-dasar Perundangundangan Indonesia. IndHill.Co : Jakarta

Bagir Manan dan Kuntana Magnar. 1997. Peranan Peraturan Perundang-undangan dalam Pembinaan Hukum Nasional. Armico : Bandung

Bernard Arief Sidharta. Refleksi Tentang Hukum. Citra Aditya Bhakti : Bandung

Haedar Nashir. Gagasan dan
Gelombang Baru Demokrasi dalam Mahfud MD. et.all. 1999. Wacana Politik dan Demokrasi Indonesia. Pustaka Pelajar : Yogyakarta

Hafifah Sj. Sumarto. 2003. Inovasi. Partisipasi Dan Good governance. Yayasan Obor Indonesia: Jakarta

Hans Kelsen. 1945. General Theory of Law and State. Russell \& Russell : New York

HAS Natabaya. 2008. Sistem Peraturan Perundangundangan. Konstitusi Press dan Tatanusa: Jakarta

Hendra Nurtjahjo. 2005. Filsafat Demokrasi. PSHTN FH UI : Jakarta

Himawan Estu Bagijo. 2007. Pembentukan Peraturan Daerah. Universitas Airlangga : Surabaya

H. Bruggink.1996. Refleksi Tentang Hukum (terj. Arif Sidharta). Citra Aditya Bhakti. Bandung

H. Rozali Abdullah. 2000. Pelaksanaan Otonomi Luas dan Isu

Federalisme Sebagai Alternatif. Raja Grafindo Persada : Jakarta

Ibnu Ruslan. 2001. Hakikat Hukum Islam. Artikel. Semipalar : 
Jakarta, www.semipalar.co.id. Akses tanggal 20 Agustus 2010

Inu Kencana Syafii. 2002. Sistem Pemerintahan Indonesia. Rineka Cipta Jakarta

Irwansyah. 2007. Audit Lingkungan sebagai Instrumen Penegakan Hukum Lingkungan. Disertasi. UNHAS : Makassar

Irawan Soejito. 1981. Hubungan Pemerintah Pusat dan Pemerintah Daerah. Bina Aksara : Jakarta

1983. Teknik Membuat Paraturan Daerah . Bina Aksara : Jakarta

Jazim Hamidi. 2008. Pembentukan Peraturan Daerah Partisipatif. Prestasi pustaka: Jakarta

- Revolusi Hukum Indonesia;

Makna. Kedudukan dan Implikasi Hukum Naskah Proklamasi 17 Agustus 1945 dalam Sistem Ketatanegaraan RI. Jakarta. Kon Press. 2006).

Jimly Asshiddiqie. 2006. Perihal Undang-Undang. Konstitusi Press: Jakarta

2004. Konstitusi dan Konstitusionalisme Indonesia, diterbitkan atas kerjasama Mehkamah Konstitusi Republik Indonesia dan Pusat Studi Hukum Tata Negara
Fakultas Hukum Universitas Indonesia : Jakarta 2000. Tata Urut PerundangUndangan Dan Problema Peraturan Daerah.

www.Mappi.com. akses tanggal 20 November 2009

--------- 2009. Format Kelembagaan Negara dan Pergeseran Kekuasaan Dalam UUD NRI Hukum Universitas Indonesia : Jakarta

---------. 2000. Tata Unit PerundangUndangan Dan Problema Peraturan Daerah.

www.Mappi.com. akses tanggal 20 November 2009 2009. Format Kelembagaan Negara dan Pergeseran Kekuasaan Dalam UUD NRI 1945 .www. Mappi.com. akses tanggal 2 November 2009

Maria Farida. 2007. Pengujian Peraturan Daerah. www. Hukumonline.com. akses tanggal 1 Desember 2009

Muchtar Sarman. 1998. Dimensi Kemiskinan: Agenda Pemikiran Sajogyo ". Kata Pengantar Mubyarto. Pusat P3R-YAE. Bogor. Edisi Terbatas.

Musa Asy'ari . 2002. Filsafat Islam, 
Sunnah Nabi dalam Berpikir. LESFI, cet 3: Yogyakarta.

Jimly Asshiddiqie. 2009. Format Kelembagaan Negara dan Pergeseran Kekuasaan Dalam UUD NRI 1945 www. Mappi.com. akses tanggal 2 November 2009

Joko Widodo. 2001. Good governance. Insan Cendekia. Surabaya

Lili Rasjidi. 1993. Filsafat Hukum, Apa itu Hukum. Remaja Rosdakarya : Bandung

Marbun. SF. ed. 2001. Pokok-pokok Pemikiran Hukum Administrasi Negara. UII Press. Yogyakarta.

Martin Jumung. 2005. Politik Lokal dan Pemerintah Daerah dalam perspektif Otonomi Daerah. Pustaka Nusantara. Jakarta

Madjid H. Abdullah. 2007. Penataan Hukum Organisasi Perangkat Daerah dalam Konteks Otonomi Daerah Berdasarkan Prinsip-prinsip Tata Pemerintahan Yang Baik Disertasi. Universitas Hasanuddin. Makassar

Maria Farida Indrati. 1996. Ilmu Perundang-undangan Dasardasar dan Pembentukannya (Bagian Pertama dari Ilmu Perundang-undangan. UI. Jakarta
Maswardi Rauf. 1998. Demokrasi dan Demokratisasi; Penjajakan Teoritis untuk Indonesia. Dalam Menimbang Masa Depan Orde Bant. Mizan. Bandung

Miriam Budiardjo.1982. Dasar-dasar Ilmu Politik. Gramedia. Jakarta

Moh. Mahfud. MD. 1998. Politik Hukum di Indonesia, cetakan pertama. LP3ES.Jakarta

Muchlis Hamdi . 2001. Filosofi Otonomi Daerah. Makalah. Jakarta

Muchsin. 2006. Ikhtisar Ilmu hukum. Badan Penerbit IBLAM. Jakarta

Muhammad Ashri. 2008. Perjanjian Kerjasama Luar Negeri sebagai Instrumen Hukum

Penyelenggaraan Pemerintahan Daerah. Disertasi. UNHAS. Makassar

Muhammad Yamin. 1982. Proklamasi dan Konstitusi. Ghalia Indonesia. Jakarta

Mukhtie Fajar. Tipe Negara Hukum. Persada Buana

Muhammad Ashri. 2008. Perjanjian Kerjasama Luar Negeri sebagai Instrumen Hukum

Penyelenggaraan Pemerintahan Daerah. Disertasi. UNHAS. 
Makassar

M. Yunus Melalatoa. 1995 Ensiklopedi Suku Bangsa di Indonesia. Jilid A-Z. Departemen Pendidikan dan
Kebudayaan : Jakarta.

Nisjar S.Karhi. 1997 Beberapa Catatan Tentang "Good governance". Jurnal Administrasi 